\title{
The immunostimulant activity of Tibb an-Nabawi natural products: a literature review
}

\section{Kajian beberapa bahan alam berbasis thibbun nabawi yang memiliki aktivitas peningkat imunitas}

\author{
Sani Ega Priani
}

Program Studi Farmasi UNISBA

Corresponding author: egapriani@gmail.com

\begin{abstract}
Background: Enhancing the immune system is very important during the Covid-19 pandemic to prevent infections and reduce the risk of disease severity. Therefore, it is necessary to use natural products with an immunostimulant effect. In Islam, there is a system of treatment or disease prevention based on AlQuran and Hadith, which is called Tibb an-Nabawi or prophetic medicine.

Objective: This research aims to conduct a literature study of Tibb an-Nabawi, which has proved to be able to increase the immune system, based on Islamic and scientific approaches.

Method: The research was based on a systematic literature review using research articles from the last ten years. The inclusion criteria were articles discussing the immunostimulatory activity of Tibb anNabawi, while the exclusion criteria were immune system enhancing herbs that were not Tibb an-Nabawi. Results: Based on the literature studies, it is known that at least six natural products based on Tibb anNabawi have scientifically proved to increase the immune system, namely black cumin, honey, dates, ginger, garlic, and pumpkin. The mechanism of immune system enhancement is different in each substance, but in general, they can increase humoral or cellular immunity. The active compounds contained in each of these ingredients contribute to the resulting immunostimulant activity.

Conclusion: Black cumin, honey, dates, ginger, garlic, and pumpkin are natural products based on $\mathrm{Al}$ Quran and Hadith, which have scientifically proved to enhance the immune system.
\end{abstract}

Keywords: Tibb an-Nabawi, Thibbun Nabawi, immune system, immunostimulant, pandemic

\section{Intisari}

Latar belakang: Peningkatan sistem imun sangat penting di masa pandemic Covid-19 untuk mencegah infeksi dan menurunkan resiko keparahan penyakit. Oleh karena itu, penggunaan bahan alam dengan efek meningkatkan aktivitas sistem imun perlu dilakukan. Dalam Islam dikenal istilah thibbun Nabawi yakni pengobatan atau pencegahan penyakit berbasis Al-Quran dan Hadist.

Tujuan: Melakukan studi literatur tentang bahan thibbun Nabawi yang terbukti meningkatkan sistem imun disertai kajian dari sisi Islami dan juga ilmiahnya.

Metode: Penelitian berbasis systematic literature review, dengan menggunakan artikel penelitian 10 tahun terakhir. Kriteria inklusi meliputi artikel-artikel membahas aktivitas imunostimulan dari bahanbahan thibbun Nabawi dan kriteria eksklusi adalah bahan alami peningkat sistem imun yang bukan merupakan thibbun Nabawi.

Hasil: Berdasarkan studi literatur diketahui bahwa sedikitnya ada 6 bahan thibbun Nabawi yang terbukti secara ilmiah mampu meningkatkan sistem imun yakni jintan hitam, madu, kurma, jahe, bawang putih, dan labu kuning. Mekanisme peningkatkan sistem imun berbeda beda untuk setiap bahan namun secara umum bahan bahan tersebut mampu meningkatkan imunitas humoral ataupun selular. Senyawa aktif yang terkandung dalam setiap bahan tersebut berkontribusi terhadap aktivitas immunostimulan yang dihasilkan

Kesimpulan: Jintan hitam, madu, kurma, jahe, bawang putih, dan labu kuning merupakan bahan alam berbasis thibbun Nabawi yang terbukti secara ilmiah mampu meningkatkan system imun.

Kata kunci : Thibbun Nabawi, sistem imun, imunostimulan, pandemik 


\section{Pendahuluan}

Covid-19 atau corona virus desease 2019 pertama kali muncul di Wuhan akhir tahun 2019. Penyakit ini kemudian berkembang dan menyebar dengan sangat cepat ke berbagai negara di dunia sehingga dinyatakan sebagai kondisi pandemik global oleh WHO pada 11 Maret 2020 (Cucinotta \& Vanelli, 2020). Di Indonesia kasus pertama Covid-19 diumumkan terjadi pada 2 Maret 2020. Jumlah total positif Covid-19 di Indonesia mencapai 1.089.308 jiwa dengan angka kematian mencapai 30.277 jiwa per 2 Februari 2021 (Satuan Tugas Penanganan COVID-19, 2021). Covid-19 diketahui dapat menular secara langsung antar manusia atapun secara tidak langsung dengan transfer droplet atau akibat kontak fisik dengan penderita ataupun terjadi ketika menyentuh permukaan benda yang terpapar virus (Shereen et al., 2020). Salah satu cara yang bisa dilakukan untuk mencegah penularan penyakit ini, selain dengan menerapkan protokol kesehatan dalam keseharian juga dapat dilakukan dengan peningkatan imunitas.

Imunitas atau kekebalan tubuh adalah pertahanan tubuh untuk melawan infeksi mikroorganisme seperti bakteri, jamur, dan virus. Sistem imun terdiri dari sel, jaringan, dan organ yang bekerja untu mengenali dan menghancurkan benda asing yang masuk ke dalam tubuh manusia. Peningkatan sistem imun sangat penting di masa pandemik seperti ini untuk mencegah infeksi dan menurunkan resiko keparahan penyakit Covid-19. Oleh karena itu, penggunaan bahan-bahan yang punya efek sebagai immunostimulan atau efek meningkatkan aktivitas sistem imun perlu dilakukan (Larenas-Linnemann et al., 2020). Efek peningkatan sistem imun tersebut dapat diperoleh dengan mengkonsumsi makanan kaya vitamin dan mineral, mengkonsumsi suplemen kesehatan, ataupun dengan mengkonsumsi bahan-bahan herbal yang terbukti punya khasiat sebagai imunostimulan (Khanna et al., 2021).

Dalam Islam kaitan dengan pengobatan dan kesehatan terdapat suatu istilah yang disebut dengan thibbun Nabawi. Thibbun Nabawi adalah segala sesuatu yang disebutkan dalam Al-Quran dan Hadist yang shahih yang berkaitan dengan kesehatan baik untuk pencegahan ataupun pengobatan penyakit. Metode pengobatan tersebut mengacu terhadap semua perkataan, pengajaran, dan tindakan Rasul yang berkaitan dengan pengobatan atau penyembuhan suatu penyakit (Fatahilah, 2016). Thibbun Nabawi dapat berupa penggunaan bahan alam seperti jintan hitam, madu, dan kurma ataupun dengan melakukan terapi seperti berbekam. Saat ini sudah banyak penelitian ilmiah di berbagai negara untuk menguji khasiat dari bahan alam berbasis thibbun Nabawi (Monette, 2012). Hasilnya terbukti bahwa bahan-bahan alam yang disebutkan dalam Al-Quran dan Hadist memiliki berbagai aktivitas farmakologi yang bermanfaat (Monette, 2012). Salah satu aktivitas yang diketahui dimiliki oleh bahan-bahan thibbun Nabawi adalah aktivitas peningkat sistem imun (imunostimulan) (Idriss et al., 2020).

Penelitian ini bertujuan untuk melakukan studi literatur tentang bahan alam berbasis thibbun Nabawi yang terbukti meningkatkan sistem imun disertai kajian dari sisi Islami dan juga 
ilmiahnya. Pembahasan mengenai senyawa aktif yang berperan dalam peningkatan sistem imun dari setiap bahan juga disertakan.

\section{Metode}

Penelitian dilakukan berbasis literature review dengan melakukan penelusuran pustaka dari berbagai jurnal nasional dan internasional. Pencarian dilakukan dengan kata kunci 'prophetic medicine', 'immune system', 'immunostimulant', 'immunomodulator'. Artikel yang digunakan untuk proses review diprioritaskan artikel yang ditulis 10 tahun terakhir. Kriteria inklusi dari studi literatur yang dilakukan adalah artikel-artikel yang membahas aktivitas imunostimulan dari bahan-bahan yang termasuk ke dalam thibbun Nabawi, dan juga bahasan tentang senyawa aktif serta mekanisme peningkatan sistem imunnya. Sedangkan kriteria eksklusinya adalah bahan yang memiliki aktivitas sistem imun namun bukan termasuk kelompok thibbun Nabawi.

\section{Hasil dan pembahasan}

Sistem imun terdiri dari organ, jaringan, dan sel yang bekerja sama membentuk pertahanan tubuh. Sistem imun ini merupakan salah satu sistem yang sangat kompleks pada tubuh manusia dengan berbagai mekanisme kerja baik secara humoral ataupun selular. Setiap bahan yang memiliki aktivitas imunostimulan memiliki mekanisme kerja dan pengaruh yang berbeda-beda.

Tabel 1. Thibbun Nabawi peningkat sistem imun

\begin{tabular}{|c|c|c|c|c|}
\hline No & Nama bahan & Bahan uji & Aktivitas & Pustaka \\
\hline \multirow[t]{2}{*}{1} & Jintan hitam & Ekstrak Etanol & $\begin{array}{l}\text { Meningkatkan jumlah IF-y dan } \\
\text { meningkatkan jumlah IgM }\end{array}$ & $\begin{array}{l}\text { (Boskabady et al., } \\
\text { 2011) }\end{array}$ \\
\hline & & Minyak & $\begin{array}{l}\text { Meningkatkan jumlah leukosit, } \\
\text { immunoglobulin, dan CD4 T helper. }\end{array}$ & $\begin{array}{l}\text { (Altınterim, 2013); } \\
\text { (Hidayati et al., 2019) }\end{array}$ \\
\hline 2 & Madu & Madu & $\begin{array}{l}\text { Meningkatkan aktivitas fagositik, } \\
\text { meningkatkan jumlah limfosit A } \\
\text { dan B, neutrofil dan imunoglobulin }\end{array}$ & $\begin{array}{l}\text { (Hegazi et al., 2015); } \\
\text { (Al-kafaween et al., } \\
\text { 2020); (Fukuda et al., } \\
\text { 2011) }\end{array}$ \\
\hline 3 & Kurma & Ekstrak air buah & $\begin{array}{l}\text { Meningkatkan kadar sel NK dan } \\
\text { IFN- } \gamma+\text { CD } 4+\end{array}$ & $\begin{array}{l}\text { (Karasawa et al., 2011); } \\
\text { (Mahassni \& Bukhari, } \\
\text { 2019) }\end{array}$ \\
\hline \multirow[t]{2}{*}{4} & Jahe & Ektrak air & $\begin{array}{l}\text { Meningkatkan immunoglobulin } \\
\text { (IgM) }\end{array}$ & $\begin{array}{l}\text { (Mahassni \& Bukhari, } \\
\text { 2019) }\end{array}$ \\
\hline & & Ekstrak etanol & $\begin{array}{l}\text { Meningkatkan aktivitas fagositik } \\
\text { makrofag }\end{array}$ & (Bintari et al., 2010) \\
\hline 5 & Bawang putih & $\begin{array}{l}\text { Ekstrak air dan } \\
\text { ekstrak etanol- } \\
\text { air } \\
\text { Minyak }\end{array}$ & $\begin{array}{l}\text { Meningkatkan aktivitas sel T, } \\
\text { makrofag, dan sel NK } \\
\text { Meningkatkan jumlah IgG, IgM, dan } \\
\text { leukosit }\end{array}$ & $\begin{array}{l}\text { (Ebrahimi et al., 2013); } \\
\text { (Moutia et al., 2018); } \\
\text { (Mohamed et al., 2016) }\end{array}$ \\
\hline \multirow[t]{2}{*}{6} & Labu kuning & Daging buah & $\begin{array}{l}\text { Meningkatkan aktivitas splenosit } \\
\text { dan makrofag }\end{array}$ & $\begin{array}{l}\text { (Kim et al., 2016); (Iwo } \\
\text { et al., 2014) }\end{array}$ \\
\hline & & Biji & $\begin{array}{l}\text { Meningkatkan indeks fagositik, } \\
\text { titer antibodi, dan jumlah sel } \\
\text { limfosit }\end{array}$ & \\
\hline
\end{tabular}


Proses studi literatur pertama diawali dengan pencarian informasi tentang berbagai bahan alam yang diketahui masuk kategori thibbun Nabawi, dengan ditunjang oleh Al-Quran dan atau Hadist. Selanjutnya dicari informasi apakah bahan-bahan alam yang termasuk ke dalam thibbun Nabawi tersebut terbukti ilmiah memiliki aktivitas sebagai peningkat imunitas. Berdasarkan proses tersebut diperoleh setidaknya 6 bahan alam yang masuk kategori thibbun Nabawi, yang terbukti ilmiah mampu meningkatkan imunitas yang tersaji dalam Tabel 1.

Bahasan detil dari sisi Islami dan ilmiah akan dilakukan untuk masing-masing bahan:

\subsection{Jintan hitam (Nigella sativa L.)}

Jintan hitam adalah salah satu bahan thibbun Nabawi. Hadist Riwayat Muslim menyatakan bahwa: 'Sesungguhnya pada jintan hitam itu terdapat obat untuk segala macam penyakit, kecuali kematian'. Berbagai penelitian ilmiah telah dilakukan untuk mengetahui aktivitas yang dimiliki oleh jintan hitam seperti antioksidan, antimikroba, antidiabetes, analgesik, antipiretik, antiinflamasi, dan antikanker (Assi et al., 2016).

Berdasarkan penelitian lain yang telah dilakukan dengan menguji pengaruh penggunaan ekstrak etanol 50\% dari jintan hitam terhadap imunitas, hasilnya menunjukkan bahwa ekstrak mampu meningkatkan produksi interferon gamma (IFN-y) (Boskabady et al., 2011). Penelitian lainnya menguji efek dari ekstrak etanol 70\% dari jintan hitam dan hasilnya menunjukkan bahwa terjadi peningkatan kadar IgM dari hewan uji. Penelitian lainnya yang dilakukan terhadap minyak jintan hitam menunjukkan minyak mampu meningkatkan sistem imun pada konsentrasi 10\% yang ditandai dengan peningkatan jumlah leukosit dan immunoglobulin (Altınterim, 2013). Minyak jintan hitam juga diketahui mampu meningkatkan respon imun selular yang ditandai dengan peningkatan jumlah sel T helper (CD4) pada konsentrasi 6,8 mg/kg BB/hari (Hidayati et al., 2019). Disisi lain, jintan hitam diketahui potensial untuk memodulasi sistem imun sehingga mengurangi terjadinya badai sitokin pada pasien Covid-19 dengan penghambatan IL-1, IL-6, IL10, IL-18, TNF- $\alpha$, and NF- $\mathrm{KB}$ (Kulyar et al., 2021). Senyawa aktif utama yang kaitannya dengan peningkatan sistem imun adalah thymoquinone, nigellidine, dan $\alpha$-hederin (Kulyar et al., 2021).

Berdasarkan kajian dari beberapa literatur, jinten hitam dalam bentuk ekstrak ataupun minyak terbukti ilmiah mampu meningkatkan sistem imun, baik secara humoral dengan peningkatan produksi imunoglobulin dan interferon (IFN-y), dan juga berpengaruh secara selular dengan peningkatan produksi leukosit dan sel T helper. Komponen-komponen sistem imun tersebut bisa berperan dalam perlindungan baik yang sifatnya bawaan ataupun adaptif. Interferon diketahui sebagai sitokin yang sangat penting kaitannya dengan perlindungan tubuh untuk infeksi virus. 


\subsection{Madu}

Madu yang diketahui sangat bermanfaat untuk kesehatan, merupakan bagian dari thibbun Nabawi yang salah satunya didasarkan pada Al-Quran surat An-Nahl ayat 68-69 "Dan Tuhanmu mewahyukan kepada lebah, 'Buatlah sarang-sarang di bukit-bukit, di pohon-pohon kayu, dan di tempat yang dibuat manusia, kemudian makanlah dari tiap-tiap (macam) buah-buahan dan tempuhlah jalan Tuhanmu yang dimudahkan bagimu. Dari perut lebah itu keluar minuman (madu) yang bermacam-macam warnanya, di dalamnya terdapat obat yang menyembuhkan bagi manusia". Secara ilmiah madu sudah terbukti memiliki berbagai aktivitas seperti antioksidan, antimikroba, antiinflamasi, antikanker. Bahan ini banyak digunakan untuk terapi luka, diabetes melitus, kanker, asma, dan penyakit kardiovaskular dan gastrointestinal (Samarghandian et al., 2017).

Madu diketahui mampu meningkatkan imunitas baik imunitas bawaan ataupun adaptif. Suatu penelitian menunjukkan bahwa pemberian madu terhadap hewan uji dengan dosis 500 $\mathrm{mg} / \mathrm{kg} / \mathrm{BB}$ tikus, mampu meningkatkan aktivitas sistem imun ditandai dengan peningkatan aktivitas fagositik dan juga peningkatan titer imunoglobulin (IgG, IgM, dan IgA) (Hegazi et al., 2015). Hal tersebut didukung oleh penelitian lainnya yang menunjukkan terjadinya peningkatan jumlah limfosit dari hewan uji yang mengkonsumsi madu (Al-kafaween et al., 2020). Penelitian lainnya memperlihatkan peningkatan neutrofil pada hewan uji setelah konsumsi madu (Fukuda et al., 2011).

Madu mengandung berbagai bahan aktif yang mendukung aktivitas farmakologinya. Madu mengandung sakarida, protein, enzim, asam amino, polifenol, flavonoid, vitamin, dan mineral (Manyi-Loh et al., 2011). Aktivitas imunostimulan dari madu diketahui muncul dari senyawa gula ataupun non gula. Nigerooligosakarida pada madu disebutkan berperan penting pada efek peningkat sistem imun disamping efek dari senyawa non gula seperti polifenol dan flavonoid. Senyawa flavonoid yang dikandung oleh madu terdiri yakni flavonol (kuersetin, kaemferol, dan pinobaksin), flavon (luteolin, apigenin, dan krisin), flavanon (naringenin, pinosembrin, dan hesperetin), isoflavon (genistein), dan antosianidin (Samarghandian et al., 2017). Mekanisme peningkat imunitas dari senyawa-senyawa tersebut perlu dikaji lebih lanjut.

\subsection{Kurma (Phoenix dactylifera L)}

Kurma adalah salah satu bahan pangan yang diketahui juga memiliki banyak khasiat bagi kesehatan. Dalam Al-Quran disampaikan tentang keutamaan buah kurma, yakni "Dan di bumi ini terdapat bagian-bagian yang berdampingan, dan kebun-kebun anggur, tanaman-tanaman, dan pohon kurma yang bercabang dan yang tidak bercabang, disirami dengan air yang sama. Kami melebihkan sebagian tanaman-tanaman itu atas sebagian yang lain tentang rasanya. Sesungguhnya pada yang demikian itu terdapat tanda-tanda (kebesaran Allah) bagi kaum yang 
berfikir." (Q.S Ar-Ra'd: 4). Hadist Rasullulah menyebutkan "Barangsiapa mengkonsumsi kurma ajwa pada pagi hari, maka pada hari itu ia tidak akan terkena racun dan sihir" (H.R Muslim).

Penelitian ilmiah tentang efek imunostimulan dari buah kurma juga telah dilakukan. Pemberiaan ekstrak air buah kurma secara in vitro terbukti mampu meningkatkan aktivitas sistem imun yang ditandai dengan peningkatan jumlah sel IFN- $\gamma+\mathrm{CD} 4+$, salah satu jenis sel darah putih yang penting dalam perlindungan tubuh terhadap infeksi (Karasawa et al., 2011). Penelitian lainnya menunjukkan aktivitas dari ekstrak air buah kurma ajwa yang diketahui mampu meningkatkan jumlah sel natural killer (NK) pada hewan uji. Sel NK diketahui termasuk sel imun bawaan, yang sangat penting untuk perlawanan tubuh pada infeksi virus dan tumor.

Buah kurma diketahui mengandung senyawa pektin dan $\beta$-glukan dan juga mengandung senyawa-senyawa polifenol. Contoh senyawa poilifenol pada buah kurma adalah luteolin, kuersetin, dan apigenin. Pektin dan $\beta$-glukan yang terkandung pada buah kurma, diketahui berperan dalam aktivitas imunomodulator. Senyawa polifenol dalam buah kurma diketahui juga mendukung aktivitasnya sebagai imunomodulator. Mekanisme dari senyawa-senyawa tersebut untuk meningkatkan sistem imun, perlu dikaji lebih lanjut (Yasin et al., 2015).

\subsection{Jahe (Zingiber offincinale L.)}

Jahe merupakan salah satu bahan herbal yang tergolong ke dalam thibbun Nabawi. Hal tersebut didasarkan pada salah satu ayat Al-Quran yakni dalam surat Al Insan ayat 17 disebutkan bahwa:'Dalam surga itu mereka diberi minum segelas yang campurannya adalah jahe'. Berbagai penelitian telah dilakukan untuk menguji aktivitas farmakologi yang dimiliki oleh jahe, dan salah satu aktivitas yang diketahui dimiliki oleh jahe adalah aktivitas peningkat sistem imun.

Penelitian ilmiah membuktikan bahwa pemberian serbuk jahe sebanyak 3\% terbukti mampu meningkatkan kadar imunoglobulin pada hewan uji (Ahmadifar et al., 2019). Penelitian lainnya menunjukkan pemberian ekstrak etanol dari jahe mampu meningkatkan sistem imun ditandai dengan peningkatan aktivitas fagositik makrofag pada hewan uji (Bintari et al., 2010). Pada penelitian menggunakan ekstrak air jahe diketahui bahwa konsumsi ekstrak air jahe mampu meningkatkan kadar imunoglobulin terutama IgM (Mahassni \& Bukhari, 2019). Berdasarkan paparan tersebut, ekstrak jahe diketahui mampu menjadi peningkat imunitas baik imunitas humoral dengan peningkatan kadar imunoglobulin ataupun imunitas selular yang ditandai oleh peningkatan aktivitas makrofag. Sel ini memiliki fungsi sebagai sel fagosit mononuklear yang utama di jaringan dalam proses fagositosis terhadap mikroorganisme dan kompleks molekul asing lainnya. Jahe diketahui mengandung banyak senyawa aktif seperti senyawa fenolik dan terpen. Senyawa fenolik utama dari jahe adalah gingerols, shogaols, dan paradols (Mao et al., 2019). Komponen 6-gingerol sebagai bahan aktif terbukti mampu meningkatkan sistem imun. Senyawa ini diketahui mampu meningkatkan aktivitas makrofag dan sel limfosit B (Smith et al., 2018). 


\subsection{Bawang putih (Allium sativum L.)}

Bawang putih yang umum digunakan sebagai bumbu masakan saat ini mulai banyak dikembangkan sebagai bahan obat. Bahan ini menjadi salah satu bagian dari thibbun Nabawi berdasarkan pada hadist: dari Ali bin Abi Thalib, beliau berkata, "Makanlah bawang putih dan berobatlah (dengan menggunakan)-nya, karena sesungguhnya di dalamnya terkandung obat (peyembuh) dari tujuh puluh macam penyakit." (HR. Ad-Dailami). Berdasarkan berbagai penelitian yang saat ini sudah dilakukan, memang terbukti bawang putih memiliki banyak manfaat, ketika dikonsumsi secara langsung, dalam bentuk serbuk kering, dalam bentuk ekstrak ataupun bentuk minyaknya.

Penelitian tentang efek peningkat imunitas dalam bawang putih sudah dilakukan sejak lama. Ekstrak air-etanol dari bawang putih diketahui dapat meningkatkan imunitas yang ditandai dengan peningkatan jumlah sel NK pada pengujian secara klinis (Ishikawa et al., 2006). Ekstrak etanol dari bawang putih diketahui dapat meningkatkan aktivitas sel limfosit dan makrofag. Aktivitas peningkatan sistem imun juga ditunjukkan oleh pemberian fraksi dari bawang putih (Ebrahimi et al., 2013; Moutia et al., 2018). Penelitian lainnya menunjukkan peningkatan aktivitas sistem imun non spesifik Oreochromis niloticus dengan pemberian bawang putih (Marentek et al., 2013). Penggunaan bawang putih dalam bentuk minyak atau dikenal dengan sebutan garlic oil diketahui dapat meningkatkan kadar IgG, IgM, dan juga leukosit pada hewan uji tikus (Mohamed et al., 2016). Beberapa hasil penelitian tersebut menunjukkan bahwa bawang putih mampu melindungi tubuh dengan peningkatan imunitas selular (sel NK, makrofag) dan juga imunitas selular (IgM dan IgG).

Senyawa utama dari bawang putih adalah senyawa organosulfur yakni diallyl thiosulfonate (allicin), diallyl sulfide (DAS), diallyl disulfide (DADS), diallyl trisulfide (DATSS-allyl-cysteine (SAC), dan S-allyl-cysteine sulfoxide (alliin). Allicin adalah salah satu senyawa organosulfur dari bawang putih yang diketahui berperang penting pada peningkatan sistem imun. Pengujian menggunakan allicin dan alliin dalam bentuk isolat murni menunjukkan terjadinya peningkatan aktifitas makrofag dan sel T (Arreola et al., 2015).

\subsection{Labu (Cucurbita moschata Duch.)}

Salah satu bagian dari thibbun Nabawi adalah labu, yang didasarkan pada Al-Quran surah As Shaffat Ayat 146: "Dan Kami tumbuhkan untuk dia sebatang pohon dari jenis labu." Selain itu dalam hadits Bukhori disebutkan bahwa Anas bin Malik bahwa ia menceritakan, "Seorang penjahit mengundang Rasulullah untuk menikmati hidangan buatannya sendiri. Anas menceritakan: maka aku pun pergi bersama Rasulullah. Lalu kepada kami disuguhkan roti gandum dan sayur berisi labu dan dendeng. Aku melihat Rasulullah selalu mencari labu dimana saja berada di sekitar nampan makanan tersebut. Sejak itu, aku pun ikut menyukai labu". 
Penelitian ilmiah menunjukkan potensi peningkat imunitas dari buah labu. Disebutkan bahwa buah labu mampu meningkatkan aktivitas splenosit dan makrofag yang diduga aktivitas itu muncul karena kandungan senyawa beta karoten yang tinggi dalam labu kuning (Kim et al., 2016). Beta-karoten juga diketahui memiliki aktivitas peningkat sistem imun dengan meningkatkan aktivitas sel T. Selain ditunjukkan oleh daging buahnya, aktivitas imunostimulan juga ditunjukkan oleh bijinya. Pemberian serbuk biji labu terhadap hewan uji terbukti mampu meningkatkan respon imun non spesifik yang ditandai dengan peningkatan indeks fagositosis dan juga respon imun spesifik yang ditandai dengan peningkatan produksi antibodi dan sel limfosit (Iwo et al., 2014). Hasil tersebut menunjukkan bahwa labu kuning dan bijinya mampu mendukung respon imun selular dengan peningkatan aktivitas fagositik yang salah satunya diperantarai oleh makrofag juga mendukung respon imun selular dengan peningkatan produksi antibodi.

Berdasarkan paparan di atas, sedikitnya ada 6 bahan alam yang tergolong ke dalam thibbun Nabawi berbasis Al-Quran dan Hadist yang juga secara ilmiah terbukti mampu meningkatkan sistem imun. Mekanisme peningkatan sistem imun berbeda-beda untuk semua bahan, namun secara umum bahan-bahan tersebut dapat meningkatkan imunitas baik non spesifik ataupun spesifik, baik imunitas humoral ataupun selular. Pengkajian mengenai mekanisme rinci peningkatan sistem imun oleh senyawa-senyawa bioaktif yang terkandung pada setiap bahan alam tersebut, perlu dilakukan. Selain itu juga perlu terus dilakukan eksplorasi mengenai bahan alam lainnya yang masuk ke dalam kelompok thibbun Nabawi yang terbukti ilmiah mampu meningkatkan sistem imun. Potensi peningkat imunitas yang dimiliki oleh bahan-bahan tersebut sangat penting untuk kondisi pandemik. Meskipun penelitian lebih lanjut untuk memastikan kemampuan peningkat imuninas bahan yang spesifik pada pencegahan infeksi Covid-19 juga perlu dilakukan.

\section{Kesimpulan}

Berdasarkan studi literatur yang telah dilakukan, diketahui bahwa sedikitnya ada 6 bahan alam berbasis thibbun Nabawi yang sudah terbukti secara ilmiah mampu meningkatkan sistem imun yakni jintan hitam, madu, kurma, jahe, bawang putih, dan labu kuning. Mekanisme peningkatkan sistem imun berbeda-beda untuk setiap bahan namun secara umum bahan bahan tersebut mampu diketahui dapat meningkatkan imunitas baik humoral ataupun selular.

\section{Ucapan terimakasih}

Terima kasih diucapkan kepada Lembaga Penelitian dan Pengabdian Kepada Masyarakat UNISBA atas bantuan dana yang diberikan untuk penyusunan studi literatur ini. 


\section{Daftar pustaka}

Ahmadifar, E., Sheikhzadeh, N., Roshanaei, K., Dargahi, N., \& Faggio, C. (2019). Can dietary ginger (Zingiber officinale) alter biochemical and immunological parameters and gene expression related to growth, immunity and antioxidant system in zebrafish (Danio rerio)? Aquaculture, 507, 341-348. doi:10.1016/j.aquaculture.2019.04.049

Al-kafaween, I. K., Hilmi, A. B. M., \& Soliman, M. M. (2020). Immunomodulatory and AntiInflammatory Potentials of Trigona Honey in the Therapy and Prevention against Respiratory Infection in Wistar Rats. International Journal of Research in Pharmaceutical Sciences, 11(3), 2955-2962. doi:10.26452/ijrps.v11i3.2385

Altınterim, B. (2013). The Effects of Nigella sativa Oil on the Immune System of Rainbow Trout With Different Application Methods. Journal of FisheriesSciences.com, 209-215. doi:10.3153/jfscom.2013021

Arreola, R., Quintero-Fabian, S., Lopez-Roa, R. I., Flores-Gutierrez, E. O., Reyes-Grajeda, J. P., Carrera-Quintanar, L., \& Ortuno-Sahagun, D. (2015). Immunomodulation and antiinflammatory effects of garlic compounds. $J$ Immunol Res, 2015, 1-13. doi:10.1155/2015/401630

Assi, M. A., Noor, M. M., Bachek, N. F., Ahmad, H., Haron, A. W., Yusoff, M. S. M., \& Rajion, M. A. (2016). The various effects of Nigella sativa on multiple body systems in human and animals. Pertanika Journal of Scholarly Research Reviews, 2(3), 1-19.

Bintari, Y., Sudarsono., \& Yuswanto, A. (2010). Pengaruh Pemberian Ekstrak Etanolik Rimpang Jahe Merah terhadap Fagositosis Makrofag pada Mencit Jantan yang Diinfeksi dengan Listeria monocytogenes. Majalah Obat Tradisional, 15(2), 80-88.

Boskabady, M. H., Keyhanmanesh, R., Khameneh, S., Doostdar, Y., \& Khakzad, M. R. (2011). Potential immunomodulation effect of the extract of Nigella sativa on ovalbumin sensitized guinea pigs. Journal of Zhejiang University-SCIENCE B (Biomedicine \& Biotechnology), 12(3), 201-209. doi:10.1631/jzus.B1000163

Cucinotta, D., \& Vanelli, M. (2020). WHO Declares COVID-19 a Pandemic. Acta Biomed, 91(1), 157160. doi:10.23750/abm.v91i1.9397

Ebrahimi, M., Hassan, Z. M., Mostafaie, A., Mehrjardi, N. Z., \& Ghazanfari, T. (2013). Purif ied protein fraction of garlic extract modulates cellular immune response against breast transplanted tumors in BALB/c mice model. Cell Journal, 15(1), 65.

Fatahilah, M. (2016). Klinik Pengobatan Thibbun Nabawi di Kota Pontianak. Jurnal Online Mahasiswa S1 Arsitektur UNTAN, 4(2).

Fukuda, M., Kobayashi, K., Hirono, Y., Miyagawa, M., Ishida, T., Ejiogu, E. C., Takeuchi, M. (2011). Jungle honey enhances immune function and antitumor activity. Evid Based Complement Alternat Med, 2011, 908743. doi:10.1093/ecam/nen086

Hegazi, A. G., Abdel-Rahman, E. H., Abd-Allah, F., \& Abdou, A. M. (2015). Influence of honey on immune status in mice-bearing ehrlich carcinoma. Journal of Clin Cell Immunol, 6(1), 1000295.

Hidayati, T., Akrom, A., Indrayanti, I., \& Sagiran, S. (2019). Black cumin seed oil increase leucocyte and CD4Thelper number in sprague-dawley rats induced with dimethylbenzanthracene. International Journal of Public Health Science (IJPHS), 8(2). doi:10.11591/ijphs.v8i2.17930

Idriss, I. D., Thani, T. M., Muhammad, H. A., \& Idris, H. S. (2020). The Prophetic Tradition in Modern Healing: A Holistic Approach to Prophetic Medicine Journal of Education and Social Sciences, 15(2), 88-94.

Ishikawa, H., Saeki, T., Otani, T., Suzuki, T., Shimozuma, K., Nishino, H., Morimoto, K. (2006). Aged garlic extract prevents a decline of NK cell number and activity in patients with advanced cancer. The Journal of Nutrition, 136(3), 816S-820S.

Iwo, M. I., Insanu, M., \& Dass, C. A. S. (2014). Development of Immunonutrient from Pumpkin (Cucurbita Moschata Duchense Ex. Lamk.) Seed. Procedia Chemistry, 13, 105-111. doi:10.1016/j.proche.2014.12.013 
Karasawa, K., Uzuhashi, Y., Hirota, M., \& Otani, H. (2011). A matured fruit extract of date palm tree (Phoenix dactylifera L.) stimulates the cellular immune system in mice. Journal of Agricultural and Food Chemistry, 59(20), 11287-11293. doi:10.1021/jf2029225

Khanna, K., Kohli, S. K., Kaur, R., Bhardwaj, A., Bhardwaj, V., Ohri, P., Ahmad, P. (2021). Herbal immune-boosters: Substantial warriors of pandemic Covid-19 battle. Phytomedicine, 85. doi:10.1016/j.phymed.2020.153361

Kim, H. Y., Nam, S. Y., Yang, S. Y., Kim, H. M., \& Jeong, H. J. (2016). Cucurbita moschata Duch. and its active component, beta-carotene effectively promote the immune responses through the activation of splenocytes and macrophages. Immunopharmacol Immunotoxicol, 38(5), 319326. doi:10.1080/08923973.2016.1202960

Kulyar, M. F., Li, R., Mehmood, K., Waqas, M., Li, K., \& Li, J. (2021). Potential influence of Nagella sativa (Black cumin) in reinforcing immune system: A hope to decelerate the COVID-19 pandemic. Phytomedicine, 85, 153277. doi:10.1016/j.phymed.2020.153277

Larenas-Linnemann, D., Rodriguez-Perez, N., Arias-Cruz, A., Blandon-Vijil, M. V., Del Rio-Navarro, B. E., Estrada-Cardona, A., Rojo-Gutierrez, M. I. (2020). Enhancing innate immunity against virus in times of COVID-19: Trying to untangle facts from fictions. World Allergy Organ J, 13(11), 100476. doi:10.1016/j.waojou.2020.100476

Mahassni, S. H., \& Bukhari, O. A. (2019). Beneficial effects of an aqueous ginger extract on the immune system cells and antibodies, hematology, and thyroid hormones in male smokers and non-smokers. Journal of Nutrition \& Intermediary Metabolism, 15, 10-17. doi:10.1016/j.jnim.2018.10.001

Manyi-Loh, C. E., Clarke, A. M., \& Ndip, N. (2011). An overview of honey: Therapeutic properties and contribution in nutrition and human health. African Journal of Microbiology Research, 5(8), 844-852.

Mao, Q. Q., Xu, X. Y., Cao, S. Y., Gan, R. Y., Corke, H., Beta, T., \& Li, H. B. (2019). Bioactive Compounds and Bioactivities of Ginger (Zingiber officinale Roscoe). Foods, 8(6), 185. doi:10.3390/foods8060185

Marentek, G. A., Manoppo, H., \& Longdong, S. N. J. (2013). Evaluation of the use of garlic (Allium sativum) in enhancing nonspecific immune response and growth of Nile Tilapia (Oreochromis niloticus). e- journal BUDIDAYA PERAIRAN, 1(1), 1-7.

Mohamed, E. H., Baiomy, A. A., Ibrahim, Z. S., \& Soliman, M. M. (2016). Modulatory effects of levamisole and garlic oil on the immune response of Wistar rats: Biochemical, immunohistochemical, molecular and immunological study. Molecular Medicine Reports, 14(3), 2755-2763. doi:10.3892/mmr.2016.5551

Monette, M. (2012). The medicine of the prophet. CMAJ, 184(12), E649-E650. doi:10.1503/cmaj.109-4228

Moutia, M., Habti, N., \& Badou, A. (2018). In Vitro and In Vivo Immunomodulator Activities of Allium sativum L. Evidence-Based Complementary and Alternative Medicine, 2018, 1-10. doi:10.1155/2018/4984659

Samarghandian, S., Farkhondeh, T., \& Samini, F. (2017). Honey and health: A review of recent clinical research. Pharmacognosy research, 9(2), 121.

Satuan Tugas Penanganan COVID-19. 2 Februari 2021. https://covid19.go.id/

Shereen, M. A., Khan, S., Kazmi, A., Bashir, N., \& Siddique, R. (2020). COVID-19 infection: Origin, transmission, and characteristics of human coronaviruses. Journal of Advanced Research, 24, 91-98. doi:10.1016/j.jare.2020.03.005

Smith, N. C., Christian, S. L., Taylor, R. G., Santander, J., \& Rise, M. L. (2018). Immune modulatory properties of 6-gingerol and resveratrol in Atlantic salmon macrophages. Molecular Immunology, 95, 10-19. doi:10.1016/j.molimm.2018.01.004

Yasin, B. R., El-Fawal, H. A., \& Mousa, S. A. (2015). Date (Phoenix dactylifera) Polyphenolics and Other Bioactive Compounds: A Traditional Islamic Remedy's Potential in Prevention of Cell Damage, Cancer Therapeutics and Beyond. International Journal of Molecular and Sciences, 16(12), 30075-30090. doi:10.3390/ijms161226210 